\title{
CAPACITY DEVELOPMENT APPROACHES FOR CHIEFS AND LOCAL GOVERNMENT AUTHORITIES IN GHANA: THE CASE OF THE ROYAL ACADAMY
}

\author{
${ }^{1}$ Boateng, K. \& ${ }^{2}$ Afranie, $S$. \\ ${ }^{1}$ Department of Social Sciences, Central University,Tema - Accra, Ghana \\ Email: sekyerehene2002@gmail.com \\ ${ }^{2}$ Centre for Social Policy Studies, University of Ghana, Legon - Accra \\ Email: safranie@ug.edu.gh
}

\begin{abstract}
Chiefs and local government authorities are instrumental in community development. However, the branding of chieftaincy by the post-colonial government as anachronistic and undemocratic and the removal of chiefs from local government structures to curtail their powers has affected their chances to be abreast of the dynamics of modern development concepts and approaches. Though currently the chieftaincy institution boasts of educated elites, some are not conversant with laws and policies on local government. Language barrier is a challenge in some cases for collaboration between the two actors as some Assembly officials speak official languages that are different from the local languages of communities in which they work. Additionally, local government authorities have been criticized for their low capacity level and their contributions to development is questioned. The study adopted qualitative approaches to examine capacity development approaches within chieftaincy and local government systems. Nineteen participants including chiefs, members of District Assemblies, key informants and local government officials were sampled through purposive and convenient sampling techniques. The study unearthed that majority of the participants were unaware about the Royal Academy, a capacity development facility for chiefs. Challenges affecting capacity development included lack of funds, change in government, traditional practices and customs, and elitism in chieftaincy. The paper concludes that capacity development can facilitate community development, and minimise conflict between chiefs and local government authorities. The paper recommends that the Ministry of Chieftaincy and Religious Affairs take steps to operationalise the commencement of activities of the Royal Academy.
\end{abstract}

\section{Keywords: Capacity development, Chiefs, Local Government Authorities, Royal Academy}

\section{Introduction}

In Ghana, chieftaincy and local government structures are guaranteed in the 1992 Constitution. Though local governance historically rested on chiefs, the Nkrumah led Convention People's Party (CPP) government gradually relinquished chiefs from their local government functions through constitutional and unconstitutional means (Ahwoi, 2017; Boafo-Arthur, 2006; Rathbone, 2000). The relationship between chiefs and government officials later improved and some of their powers and functions restored to them after the overthrow of the Nkrumah government (Anamzoya, 2008; Brempong, 2007). The current local government legislation, failed to clearly define the roles of chiefs in local government and also make them automatic members of the Assembly. The lack of institutional representation of chiefs in local government is due to the roles chiefs played in the colonial administration and the perception by African political elites that chiefs were collaborators of the 
colonial regime (Brempong, 2007; Rathbone, 2000). Chieftaincy was regarded as undemocratic and against the ethos of the regime that restructured local government in the 1980s (Boateng \& Afranie, 2020a; Turmann, 2010). The lack of institutional representation of chiefs in the loal government system made chiefs perceive the decentralisation process as nontransparent (Dawda \& Dapilah, 2013) and deterred them from collaborating with local government authorities.

Additionally, the low capacity of local government authorities and chiefs affected the level of collaboration. Local government structures in Ghana are characterised by weak technical human resource which stems from nepotism that characterise the selection and appointment of Metropolitan, Municipal and District Chief Executives (MMDCEs) and government appointees into the Assembly (Ayee, 1999). In the appointment of Chief Executives and government appointees of a district assembly, preference is given to party supporters most of who lack the required competence to participate effectively in Assembly deliberations. Some government officials have labeled most district assembly members as inept and worthless. Such a perception of local government authorities often antagonize the relationship between them and the technocrats of decentralised departments at the district level.

The disregard for the chieftaincy institution by the Convention People's Party (CPP) and its supporters at the grassroots (Boafo-Arthur, 2006; Rathbone, 2000) made the institution unattractive (Brempong, 2007). Chieftaincy is currently partially characterised by educated professionals who are perceived by kingmakers as better positioned to utilise their social networks for community development (Akrong, 2006; Steegstra, 2006; Tonah, 2012). Despite elitism characterising the chieftaincy institution in contemporary times, there are many chiefs who are uneducated and the language barrier remains a huge challenge to their collaboration with local government officials and other developmental partners (Dawda \& Dapilah, 2013). Some chiefs are still uninformed about modern trends in public administration and local government structures. The effect is that the relationship between chiefs and local government authorities is at times characterised by conflict, tensions and mistrust (Turmann, 2010) thereby affecting community development. Also, some chiefs lack the capacity to efficiently represent the interest of their people and have weak social mobilisation skills (Turmann, 2010).

In the face of the antangonistic relationship between chiefs and local government authorities and low capacity level of the latter, this study examined capacity development of chiefs and local government authorities and the factors accounting for the delay in the commencement of the Royal Academy, a capacity development facility for chiefs. Studies on chieftaincy and local government have often devoted attention to institutional representation (Ayee, 2006), partnership modalities (Dawda \& Dapilah, 2013; Mahama, 2009), role of chiefs in development (Boateng et al, 2016; Boateng, 2010), the relationship between chiefs and government officials (Taabazuing et al, 2012; Brempong, 2007; Rathbone, 2000), collaboration between chiefs and local government authorities (Arthur \& Dawda, 2015; Boateng \& Afranie, 2020b) and the primacy of the chieftaincy institution within a democratic dispensation (Boateng \& Afranie, 2020a). Apart from Turmann (2010) who looked at capacity development of chiefs and local government authorities with emphasis on the Royal Academy, its components and executing institutions, no further study has investigated why the Academy has not been operationalised and how in its absence, chiefs and local government authorities develop their capacity. The researchers are of the conviction that the organisation of capacity development programs for chiefs and local government authorities will enhance collaboration between them and minimise conflicts that characterise their relationship and consequently enhance community development.

Capacity development (CD) has been espoused to amalgamate complementary concepts like capacity building, institutional building, and human 
development among others. Unification of these concepts integrates diverse stakeholders who consider the concept as part of the development puzzle. Capacity is conceptualised as the ability of people, organisations and society as a whole to manage their affairs successfully. Capacity development is thus a change process in which people collaboratively work to unleash, strengthen, create, adapt and maintain capacity over a period of time (OECD, 2006). CD as an endogenous process is aimed at improving the skills and potentials of individuals, enhancing productivity of an organisation, and creating sustainable institutions to optimise the effective utilisation of human, financial and physical resources for the attainment of goals at the individual, organizational, institutional and societal levels.

It is a process through which individuals, groups, organisations, institutions, and societies increase their abilities to perform functions, solve problems, achieve objectives, understand and deal with their development needs in a sustainable manner. The paper is structured as follows: an overview of the Royal Academy, methodology, findings and discussion delineate conceptualisation of capacity development, the royal academy and challenges that beset capacity development of chiefs and local government authorities. The final section is the conclusion and recommendations.

\section{An Overview of the Royal Academy}

For the chieftaincy institution to be viable in contemporary Africa, the capacity of chiefs must be developed for them to embrace the developmental challenges confronting their subjects (Boafo-Arthur, 2006). Currently, the relationship between District Assemblies and chiefs largely pertains to land allocation for socio-economic development and performance of ceremonial functions at programs organised by the Assemblies. Capacity development programs will enable chiefs and local government authorities play vital roles as partners and agents of community development at the grassroots. That is, capacity development of chiefs for instance, will enable them implement sustainable projects and programs that will safeguard the current and yet to be born generations, thereby ensuring the continuance of society. In a workshop on the interface between traditional political system and local government structures and their functions, chiefs called for the establishment of a Royal Academy. Odeneho Gyapong Ababio II, the then President of the National House of Chiefs, echoed the need for the Ministry of Local Government and Rural Development and Environment to formulate modalities detailing the facilities that the college would offer and how they will commensurate with the changing status and stature of chiefs (Report on workshop on the Interface of Traditional Political system, 2006).

The academy was developed by the Ministry of Local Government and Rural Development in collaboration with the Ministry of Chieftaincy and Culture and the Institute of Local Government Studies (ILGS) (Turmann, 2010). Under the German Development Cooperation (DED), a curriculum for the academy was developed. As a virtual academy, the curriculum had thematic topics that sought to develop the capacity of chiefs. The academy was to equip stakeholders to perform their functions efficiently and enhance the collaboration between chiefs and local government authorities. These two stakeholders are functional for the materialisation of the objectives of decentralisation. Among the functions of the academy was the harmonisation of chieftaincy to meet the changing trends of governance while still maintaining the core values of the institution of chieftaincy, serve as a platform for training chiefs to be able to effectively discharge their responsibilities and serve as an avenue for addressing some anomalies surrounding the status of chiefs in the decentralised system (Turmann, 2010). Currently, the role of chiefs in local government is unclear. The lack of clarity is caused by lack of political will, ill-defined relationship between chiefs and government units, and chieftaincy disputes among others (Ayee, 2007). Additionally, some personnel of the District Assemblies look down on the chieftaincy institution at the grassroots. The Royal Academy was thus a good step towards 
addressing the anomalies surrounding chieftaincy as far as local governance is concerned. Other functions of the Academy included ensuring that chiefs and local government authorities are educated on good governance and partnership modalities between them and other development partners. The fundamental purpose of the Royal Academy was to develop the capacity of the chiefs thus making them development partners for a conflict free collaboration with local government authorities.

The proposed components included stakeholder meetings, sensitization workshops and an action plan program at the regional levels, database creation and educational training programs for chiefs. The essence of the regional stakeholder meetings between chiefs and the sector ministries was to among other things, discuss the expectations of the academy, and discuss the implementation and monitoring of the academy. Additionally, regional sensitization workshops were aimed at assessing the level of experience and educational qualifications and types of contributions that chiefs will make to the development of the academy. The role of ILGS in this endeavor, was to establish regional committees for planning, implementation and monitoring of the academy in each region. Thirdly, the development of an accurate database of chiefs was to aid government in planning and decision making regarding the chieftaincy institution. Lastly, the development of specialized and contemporary capacity development programs to meet the exigencies of the transformations within the chieftaincy institution was the prerogative of the ILGS. The secretariats for the academy were to be created in Accra and Tamale to plan, organise, implement and coordinate the affairs of the academy (Turmann, 2010). This paper examined the level of awareness of participants on the Royal Academy and also explored the factors accounting for the delay in the commencement of the program.

\section{Methodology}

The study was conducted in New Juaben in the Eastern Region of Ghana. The area falls within the New Juaben South and New Juaben North Municipal Assemblies. A qualitative approach was adopted for data collection and analysis. Research questions that guided the study included: How do chiefs and local government authorities develop their capacity? What are the challenges besetting operationalization of the Royal Academy and capacity development as a whole? A combination of probability and non-probability sampling techniques were used to select 19 participants for the study. Purposeful sampling was used to select four key informants including the President and Registrar of the Eastern Regional House of Chiefs (ERHC), the Dean of Research and Graduate Studies at the Institute of Local Government Studies (ILGS) and a former Director of ILGS. This method allowed the researchers to select participants better positioned by virtue of their knowledge, skills and experience to answer the research questions (Patton, 2002; Twumasi, 2001; Bernard, 2000).

Six chiefs who happened to be present at the office of the Juaben Traditional Council at the time of our visit were selected through convenient sampling technique. Three senior officials of the Assembly including a Planning Officer, Coordinating Director and, a Finance Officer were selected through simple random sampling. Senior officials in the planning unit, finance office and the two Coordinating Directors of the two Assemblies were placed in three respective containers. A name from each was subsequently picked from each container after thoroughly shuffling the names. A similar exercise was undertaken to select six local government authorities (three each from the two Assemblies). Data was collected through key informant and indepth interviews with the aid of a semi-structured interview guide. Each interview session lasted about 60 minutes and were audio-taped recorded. Data analysis was concurrently conducted. Inductive data analysis as part of theme building was conducted by organising data into units of information (Patton 2002). Participants were adequately oriented on the objectives of the research and written and oral consent were sought prior to data collection. Trustworthiness of the study was achieved through iterative questioning, methodological triangulation 
and member validation (Bryman, 2012; Shenton, 2004).

\section{Findings and Discussion}

\section{Conceptualising Capacity Development}

Participants used capacity development and capacity building interchangeably. Capacity building (CB) connotes the development of knowledge, skills and attitudes in individuals and groups of people relevant in design, development, management and maintenance of institutional and operational infrastructures and processes that are locally meaningful (Groot \& van der Molen, 2000). CB therefore encapsulates steps aimed at developing capabilities of individuals and organisations to undertake assigned tasks efficiently and effectively. Capacity development was conceptualised as the process of equipping an individual with the skills, knowledge, and tools, required to perform assigned jobs. The transfer of these skills was through training, seminars and workshops. The following was how some participants conceived the concept:

It's equipping a person, entity, an organisation or a nation to be able to do something. When you have capacity you're able to do something to better the conditions of your people. In this case, capacity development goes beyond training; it's about building the human resources, the technological resources, putting in place the proper infrastructure, looking at processes that add value, and also building the capacity to innovate and learn to manage change. (KI 3)

Capacity development is equipping functionaries in a particular level of governance with the skills, competencies, and knowledge levels to be able to contribute positively in their area of jurisdiction to the development agenda of the country. (KI 2)

Capacity building is an attempt to develop the human resources of an institution with the paramount objective of enabling them to perform their functions effectively after going through the training or workshop. (IDI 5)

Capacity development as a process takes a multidimensional approach by combining people, institutions, and practices primarily to develop and facilitate the materialisation of predetermined goals. Significantly, the concept recognises partnerships between formal and indigenous institutions to achieve some common goals. The emphasis of CD entails the development of the capacity of individuals, institutions, and broader societal level. Capacity has been conceived as the ability of individuals, organisations, or systems to perform functions effectively, efficiently, and sustainably (UNDP, 1998).

From the above conceptualisation, three dimensions of capacity can be inferred. The first is the fact that capacity is a continuing process. The capacity of an individual or organisation requires continuous renewal and investment to achieve organisational efficiency. The second aspect is that capacity development places premium on human resource development and how it is utilised. The utilisation of human resources in this context is geared towards enhancing an individual or organisation to perform assigned tasks. So efficiency of chiefs and local government authorities requires continuous human resource development for them to maximise their potentials. Thirdly, capacity development concentrates on the entire context within which an individual or an institution undertakes its assigned functions. Institutions and individuals are interwoven in a diverse, complex and overlapping web of environment. The political, social, cultural, economic and bureaucratic environment interact to influence how people and institutions behave in the performance of their tasks. Participants acknowledged the need for the capacity of chiefs and local government authorities to be developed to minimise conflicts and promote effective collaboration among them. 


\section{Levels of Capacity Development}

Capacity development addresses issues at three levels or dimensions namely, societal/system level, organizational/entity, and group-of-people or individual level (UNDP, 1998). The individual dimension addresses the need for chiefs and local government authorities to perform their functions effectively within their respective jurisdictions. The task of the Ministries of Chieftaincy and Religious Affairs and Local Government and Rural Development, as well as other agencies for capacity development is to conduct effective capacity assessment and development programs.

Capacity assessment entails an evaluation of individuals within the chieftaincy and local government structures to assess capacity that is needed to be developed. Issues of critical development may include improving interpersonal communication among chiefs and local government authorities, psychological topics such as emotional management among others. Capacity development at this level emphasizes skills and knowledge enhancement of chiefs and local government authorities. For the Assembly members, orientation on their functions, challenges besetting their office as well as effective communication and collaboration with stakeholders at the community level are emphasized during capacity development programs organised for them. Participants acknowledged that capacity development at this level had the propensity to reduce the psychological causes of conflicts. A participant added:

As you can see, capacity development at the individual level will minimise the cause of conflicts between chiefs and local government authorities. Training on stress management, differences in temperaments for instance will allow chiefs and local government authorities the opportunity to appreciate themselves better whenever differences emerge in their interactions. (IDI 2)

At the institutional level capacity development entails training and skills development on the objectives and missions of the two institutions. Traditionally, the training chiefs got was the knowledge passed onto them during the period of confinement that preceded their installation. The transformations in the chieftaincy institution has called for a realignment of the institution to be responsive to the developmental needs of the vulnerable. Institutional capacity development considers training in the procedures, processes, rules, and regulations that govern the operations of both the chieftaincy and local government institutions. Participants indicated that training and seminars, were organised for them on issues such as the standing orders of the Assembly and the Houses of Chiefs, procedures for conflict management, new legislations such as the chieftaincy and local government acts.

For chiefs, training sections were conducted on topics such as rights of children, child marriage, women empowerment and fundamental human rights of the vulnerable and social justice. Assembly members indicated that workshops and training were at times organised for them before the commencement of their work. A local government official opined that:

Previously, before they start their work in the Assembly, we used to develop their capacity. We take them through the procedures of the Assembly. So many of them don't understand how things are done, even those who have been working in it for long at times are found wanting how much more someone who was just elected. So there's the need to develop the capacity of Assembly members for them to know the procedures in the Assembly. So without developing their capacity, some of them just come and walk through the Assembly without making any meaningful impact on their people. (IDI 3)

Another Assembly member argued that:

People have questioned the capacity level of Assembly members for some time now. Some have questioned the election of people without the required level of expertise into 
the Assembly. So it is vital for capacity development programs to be organised for them to positively make an input in community development. (IDI 14)

Training at this level was instrumental in minimising both intergroup and intragroup conflicts. Effective capacity development programs equipped actors to perform their roles efficiently. One of the causes of contestations between chiefs and local government authorities was a failure on the part of stakeholders to comprehend the procedures and processes that governed the Assembly. Capacity development at the institutional level therefore, encourages effective collaboration between stakeholders of the decentralised process.

The highest level of capacity development initiative was at the societal or enabling environmental level. At this level, stakeholders participated in planning and policy formulation. Planning of programs that were tailored at meeting the needs of the most vulnerable and disadvantaged members of society and safeguard their fundamental human rights. Participants recalled collaborating with local government authorities in policy formulation at the municipal level especially after the flooding and landslide that destroyed life and property and internally displaced hundreds of people between 2016 to 2018. Also, some indicated attending orientation programs on national policies that had a bearing on chieftaincy and local government systems. Capacity at this level centered on land policy, procurement processes, allocation of public resources like stool lands, revenue utilisation, and accountability of statutory allocations to the District Assemblies and National and Regional Houses of Chiefs. Participants indicated that workshops were organised on their roles in the materialisation of the Sustainable Development Goals (SDGs). A chief indicated that:

I recall that we participated in some traning on Sustainable Development Goals (SDGs). The essence was to orient us on the SGDs and also our expected roles in ensuring that the predetermined goals are achieved within the estimated time frame. For this workshop, we did not pay anything for participating.

Funds for some of these workshops were provided by the organising institutions like the Municipal Assembly, Zoomlion Ghana Limited, the National House of Chiefs, the United Nations Development Program (UNDP), Integrated Social Development Centre (ISODEC) and Conrad Adenauer-Stiftung (KAS) foundation. As at the time of gathering data, the Regional House of Chiefs had sent a proposal to the office of the Conrad-Adenauer-Stiftung (KAS) foundation for assistance in developing the capacity of chiefs and other stakeholders on sanitation and environmental management. Training by the UNDP on conflict management and other thematic areas has reduced with the establishment of the National Peace Council, this is because funds for the House of Chiefs are now sent to the Peace Council which is mandated to promote peace and stability in the country. The Registrar of the Eastern Regional House of Chiefs added that:

Formerly, we used to get periodic funding from the United Nations Development Programme (UNDP) for capacity development. However, since the establishment of the National Peace Council, funding from the institution has reduced. I suspect that that has happened because the National Peace Council has a paramount objective of ensuirng peaceful co-existence in the country. Aside the UNDP, the House of Chiefs also get funding from ConradAdenauer-Stiftung (KAS) foundation for capacity development.

\section{Familiarity / Awareness of The Royal Academy}

The majority of participants with the exception of two key informants, had no idea about the Royal Academy and its objectives. The lack of awareness is due to the fact that the project has not commenced since its conception in December 2006. Some participants however, mentioned the Otumfuo Centre for Traditional Leadership (OCTL) and the Homowo School as some capacity development 
institutions they were familiar with. These institutions were established to bring chiefs up to speed with the paradigm shift within traditional leadership and equip them with the necessary tools that would make them play significant roles in socioeconomic development. The Homowo School is organised for chiefs in the Greater Accra Region while capacity development organised by the Otumfuo Centre for Traditional Leadership OCTL, is opened to chiefs once the participant is able to foot the bill. The following were some of the views of participants:

Well, I have not heard of anything called a Royal Academy. The only capacity development institution I have heard about is the Otumfuo school, which I understand is affiliated to a tertiary institution in the country. So a capacity development institution called a Royal Academy is new to me. (IDI 14)

I know of the Homowo School which is located in Accra, the capital of the country. Organisers used to undertake periodic capacity development activities for traditional authorities in the region. I don't know if it is still operational or not. So for a Royal Acadamy, that was originally established to undertake capacity development of chiefs, I have not heard about it at all. (IDI 11)

Yes, there was a planned initiative called the Royal Academy. I served on a team that was constituted to work on the curriculum for the commencement of this virtual capacity development institution for chiefs. The essence was to have this institution to enhance the capacity of chiefs so as to promote effective collaboration with development partners and assist chiefs perform their developmental functions well. (KI 2)

\section{Challenges to Capacity Development}

In this section, the challenges of the royal academy and capacity development in general are discussed. Participants indicated that lack of funds constrained the operationalisation of the academy. Initially, majority of the funds were expected to come from the German Development Cooperation (DED). The modification of the orientation of DED, shattered the impetus of the originators to push for the commencement of the project. With the change in fortunes of the expected financier, the Ministries of Local Government and Rural Development and the Chieftaincy and Religious Affairs and the National House of Chiefs could not secure funding for the project. The lack of financial allocation stems from the inability of the state to generate resources internally to fund projected programs. A participant added:

Funding for the program is not there that's why we haven't been able to operationalise the Royal Academy. You see when we initiated this project we thought that funding was going to come from external donor. We have the structures, the facilities to kick start this program but when the people come, they'll eat, they'll drink and these are chiefs we're talking about. So we need funds to develop the faculty, to buy books for them when they enroll on the program. (KI 3)

Everything that was needed for the commencement of the program was in place except for funds. When you initiate a project and your only source of funding is external source and it backfires, and you're unable to think outside the box, your initiatives will suffer. So the major challenge besetting the commencement of the project is that funding is completely not there. Other than that, the project would've commenced long ago. (KI 2)

Closely related to the financial constraints was the change in political leadership at the national level. Motivation for the Academy which was crafted under the New Patriotic Party (NPP) government vanished as it was not the topmost priority of the 
National Democratic Congress (NDC) administration that won the 2008 general elections. Although the NDC government under the late John Evans Atta Mills maintained the chieftaincy ministry created by the former government, it failed to allocate the needed resources for the commencement of the project. In Ghana, countless projects and programs commenced by previous governments are neglected when there is a change in government (Akwei, Damoah \& AmankwahAmoah, 2020; Republic of Ghana, 2015) and the Royal Academy was no exception. Thus to some, the lack of commitment of central government towards the implementation delayed the commencement of the project. A participant added:

I suspect also that it coincided with a change of government because for this project, you needed a certain clout to do this kind of thing. So when it appeared that this project wasn't their top most priority, and especially when you don't have the resources to implement it yourself, your own ideas fly. So in short, finance and change of government are some of the challenges that have curtailed the implementation of the royal academy. (KI 3)

In Ghana it is very possible for projects commenced by a previous government not to be completed. There are plenty of projects which were started by previous political administrations that have not been completed because the government that begun them are out of power. So, the change of political administration from the NPP to the NDC in 2008, to me did not go in the favour of the program. I think the project was not in their plans at all. (KI 2)

Financial impediments affected the routine organisation of training and workshops for chiefs and local government authorities to enhance their capacity. The Eastern Regional House of Chiefs occasionally organised training for chiefs whenever funds were available to strengthen their capacity. According to the Registrar of the Eastern Regional
House, the House used to organise training and workshops for chiefs and other stakeholders to enhance their skills and knowledge base. Lack of funds was the reason for the inability of the House to complete training on the new Chieftaincy Act for chiefs in the region. The unavailability of funds has prevented chiefs from knowing their expectations as enshrined in the new Chieftaincy Act. The unavailability of funds affected the Assembly's routine orientation that it was mandated to organise for Assembly members prior to the commencement of their work. Projected workshops and training programs that appeared on the Assembly's budget never materialized as a result of lack of funds. However, the Regional Coordinating Council (RCC) once in a while organised workshops for Assembly members and officials at the Municipal Assembly. Closely related to financial constraint was traditional practices and customs. Chiefs by tradition do not travel without their entourage made up of various sub chiefs and other functionaries. Attending training programs for days meant providing accommodation, food, servicing of their vehicles and other incentives for chiefs and their entourage. The cost for these incentives, deterred organisers from mobilising capacity development programs for chiefs. When asked how traditional practices and customs inhibited capacity development, a participant explained that:

The Institute of Local Government Studies planned a series of training sessions for chiefs but it was stopped along the way. This is because you'll invite one chief for training and they'll come with their entourage. They come with so many functionaries such as those who carry their chairs, umbrellas, sandals, among others. So when they come they're on your budget. So in this case, you need to expand the resources needed for the training such as water, classrooms and food. These are some of the challenges that beset capacity development of chiefs. (KI 4)

The heterogeneous nature of the Ghanaian society coupled with elitism in chieftaincy affected capacity development. The numerous ethnic groups had 
diverse developmental needs and challenges. Therefore, efforts to bring chiefs into a box when they have different developmental needs by virtue of the different environments and different responsibilities they render to their people, will mean that some needs of chiefs will not be met. As has already been noted, a lot of the chiefs now are professionals, with knowledge and skills in diverse aspects of human existence. The challenge of the elitist inclination of chieftaincy relates to the content of capacity development programs for participants. A participant indicated:

So if you have a room full of members of the National House of Chiefs; you have prominent paramount kings who are professionals with diverse educational qualification, what at all are you going to teach these learned chiefs? What you can build their capacity on is what chieftaincy can do to influence national policy. (KI 3)

However, the above challenge can be minimised when effective capacity development assessments are conducted. As has been illustrated earlier, a proper capacity assessment will help identify the necessary skills that need to be enhanced. Thematic areas such as national and international laws on human rights, new legislations, investment and private-public partnership, project formulation, funding and management and conflict management will enhance the content of capacity development programs that will be tailored to the needs of chiefs and their subjects.

\section{Conclusion and Recommendations}

The framers of the 1992 Constitution of Ghana guaranteed the chieftaincy institution by virtue of its significance and the fact that the institution is interwoven in the social fabric of the country. Despite the installation of educated professionals as chiefs, some are not conversant with legislations on local government and public administration. Some local government authorities have been criticised for their low level of capacity, inhibiting them from making meaningful contributions to growth and development of their electoral areas. This phenomenon, coupled with the lack of clarity regarding the functions of chiefs in local government, account for the conflict that characterise the relationship between them at the grassroots.

The paper examined capacity development within the chieftaincy institution and the local government system in New Juaben, Ghana. The paper supports the view that capacity development for chiefs and local government authorities will minimise conflict between them especially those that surround role performance. Although participants were able to conceptualise the essence of capacity development, dimensions and forms the process took, training programs were not frequently organised for chiefs and local government authorities. The only capacity development program for Assembly members was the orientation that they received prior to the commencement of their work.

From the study, not much has been done to ensure the achievement of the objectives of the Royal Academy. This was illustrated by the fact that participants with the exception of some key informants, did not know about this project by the National House of Chiefs and the Ministry in charge of Local Government and Rural Development. Challenges of the Academy and capacity development in general included lack of funds, changing fortunes of sponsoring institutions, change of government, tradition and customs, the heterogeneous nature of the Ghanaian society and elitism in chieftaincy institution.

In the light of the above challenges and the fact that the Homowo School is organised for chiefs in Greater Accra region, it is imperative for the central government to financially support the OCTL so that numerous chiefs can attend training organised by the center at relatively cheaper rate as some chiefs who wanted to attend the Otumfuo School complained about the rates for participants. The study recommends that the Ministry of Chieftaincy and 
Religious Affairs in collaboration with the Ministry of Local Government and Rural Development should take steps to expand the scope of the Royal Academy to include capacity development for local government authorities and operationalise the system.

\section{Acknowledgements}

A substantial part of the data for this paper was taken from the data collected by the lead author for $\mathrm{PhD}$ purposes which was funded by the University of Ghana Carnegie Next Generation of Academics in Africa (UG CNGAA) project.

\section{References}

Ahwoi, K. (2017). Local Government and Decentralization in Ghana. Winmat Publishing Limited.

Akrong, A. (2006). Religion and Traditional leadership in Ghana. In I.K. Odotei, \& A.K. Awedoba (Eds.), Chieftaincy in Ghana: Culture, Governance and Development (pp. 193-212). Accra: Sub-Saharan Publishers.

Akwei, C., Damoah, I. S., \& Amankwah-Amoah, J. (2020). The Effects of Politics on the Implementation of Government Programs/Projects: Insights from a Developing Economy, Politics \& Policy, 48 (6), 1161-1201 https;//doi:10.1111/polp.12384

Anamzoya, S. A. (2008). Politicization, elite manipulation or institutional weaknesses? The search for alternative explanations to the Dagbon chieftaincy disputes in Northern Ghana. Research Review, 24 (1), 1-25.

Arthur, D. D., \& Dawda, D. T. (2015). Promoting rural development through chieftaincy institutions and district assemblies: Evidence from Sissala East District, Upper West Region of Ghana. Ghana Journal of Development Studies, 12 (1\&2), 165-177. http://dx.doi.org/10.4314/gjdsv13i1\&2.10.

Ayee, J. R. A (2007). Traditional Leadership and Local Governance in Africa: The Ghanaian Experience, presented at the Fourth National
Annual Local Government Conference, Southern Sun - Elangeni, Durban, July 2007. Ayee, J. R.A. (2006). Some thoughts on the institutional representation of chiefs in the District Assemblies and the Sub-District Structures. In I.K. Odotei, \& A.K. Awedoba (Eds.), Chieftaincy in Ghana: Culture, Governance and Development (pp. 55-63). Accra: Sub-Saharan Publishers.

Ayee, J.R.A. (1999). Decentralization and conflict: The case of district chief executives and members of parliament in Ghana. Ghana: Friedrich Ebert Foundation.

Bernard, R.H. (2000). Social Research Methods: Qualitative and Quantitative Approaches. Thousand Oaks, CA: Sage: Publications.

Boafo-Arthur, K. (2006). Chieftaincy in Ghana: Challenges and prospects in the $21^{\text {st }}$ century. In I.K. Odotei, \& A.K. Awedoba (Eds.), Chieftaincy in Ghana: Culture, Governance and Development (pp. 145-168). Accra: SubSaharan Publishers.

Boateng, K., \& Afranie, S. (2020a). Chieftaincy: An Anachronistic Institution within a Democratic Dispensation? The Case of a Traditional Political System in Ghana. Ghana Journal of Development Studies, 17 (1), 25-47 http://dx.doi.org/10.4314/gjds.v17i1.2

Boateng, K., \& Afranie, S. (2020b). All Hands on Deck: The Process and Activities of Collaboration between Chiefs and Local Government Authorities in Ghana. Ghana Journal of Development Studies, 17 (1), 92113 http://dx.doi.org/10.4314/gjds.v17i1.5

Boateng, K., Afranie, S., \& Amoah, S.K. (2016). Social mobilisation in the midst of social change: The Case of traditional authorities in Ghana. Journal of Educational and Social $\begin{array}{llll}\text { Research, } & 6 & \text { (2), } & \text { 103-112. }\end{array}$ https;//doi:10.5901/jesr.2016.v6n2p103

Boateng, K. (2010). Chiefs as agents of development: A study of chieftaincy and community development in the Asante Juaben Traditional Area. (Unpublished MPhil 
thesis), Department of Sociology, University of Ghana, Legon.

Brempong, N.A. (2007). Transformation in Traditional Rule in Ghana, 1951-1996. Legon: Institute of African Studies.

Bryman, A. (2012). Social research methods $\left(4^{\text {th }}\right.$ ed). Oxford: Oxford University Press Inc.

Dawda, T.D., \& Dapilah, F. (2013). Challenges of the Collaboration between Formal Local Government Actors and the Chieftaincy Institution in Ghana: Lessons from the Sissala East District of the Upper West Region of Ghana. International Journal of Humanities and Social Science, 3 (12), 238-246.

Groot, R., \& Van der Molen, P. (Eds.) (2000). Workshop on Capacity Building in Land Administration for Developing Countries. International Institute for Geo-Information Science and Earth Observation.

Mahama, C. (2009). Local economic development and local government in Ghana: Navigating a viable path to reform. Journal of Local Government Studies, 1 (1), 29-54.

Organization for European Cooperation and Development (OECD) (2006). The Challenge of Capacity Development: Working Towards Good Practice. DAC Network for Governance.

Patton, M.Q. (2002). Qualitative evaluation and research methods (3rd ed.). Thousand Oaks, CA: Sage Publications, Inc.

Rathbone, R. (2000). Nkrumah and the Chiefs: The politics of Chieftaincy in Ghana 1951-60. Ohio: Ohio University Press.

Republic of Ghana (2015). The Budget Highlights. Ministry of Finance and Economic Policy. Available at: https://www.mofep.gov.gh/sites/default/files/ budget-statements/Budget-Highlights2015.pdf Accessed: 14 ${ }^{\text {th }}$ May 2020.

Report on workshop on the Interface of Traditional Political system and the Decentralized Local
Government Structures and their Functions. Organized by Ministry of Local Government Rural Development and Environment and Ministry of Chieftaincy Affairs and Culture. December 21, 2006 held at the National House of Chiefs in Kumasi.

Shenton, A.K. (2004). Strategies for ensuring trustworthiness in qualitative research projects. Education for Information (22), 6375.

Steegstra, M. (2006). White Chiefs and Queens in Ghana: Personification of 'Development'. In I.K. Odotei, \& A.K. Awedoba (Eds.) Chieftaincy in Ghana: Culture, Governance and Development, (pp.603-620). Accra: SubSaharan Publishers.

Taabazuing, J., Armah, F., Dixon, J., \& Luginaah, I. (2012). The Relationship Between Traditional Authorities and Decentralized Structures in Ghana: Conflicting Roles or A Struggle for Power and Legitimacy. International Journal of Development and Conflict, 2 (3), 1-25.

Tonah, S. (2012). The politicisation of a chieftaincy conflict: The case of Dagbon, northern Ghana". Nordic Journal of African Studies, 21(1), 1-20.

Turmann, A. (2010). Capacity Building programme for Traditional Authorities in Ghana: A Case of a Royal Academy. Journal of Local Government Studies, 2 (1), 92-108.

Twumasi, P.A. (2001). Social Research in rural communities. ( $2^{\text {nd }}$ Ed). Accra: Ghana Universities Press.

United Nations Development Programme (1998). Capacity Assessment and Development. New York: UNDP. Retrieved from:

https://www.cbd.int/doc/pa/tools/Capacity\%20asse ssment\%20and\%20development.pdf 